\title{
STUDI KOMPETENSI INTI DAERAH DI KABUPATEN BELU PROVINSI NUSA TENGGARA TIMUR
}

\author{
Thomas Ola Langoday \\ Universitas Widya Mandira, Kupang
}

\begin{abstract}
Core competence area is a collection of skills and technologies that enable an organization can provide its own benefits for its customers. Thus, the high unique core competencies needed to achieve organizational objectives. The uniqueness of the organization can make it difficult for competitors to imitate. By adopting the concept of one village and one product and concept SAKA SAKTI (one county / city of the core competencies) then to build the competitiveness of the region required the creation of core competencies for the area. This is necessary so that all resources and capabilities of the region focused on efforts to create a core competency. Based on the seven aspects of the value chain, namely raw materials, human resources, competitiveness, infrastructure, technology and information, social capital and institutional and security conditions, it is found that the commodity becomes a core competence area in Belu Regency is a patchouli plant and the results of various scent of patchouli oil. Patchouli plants available uniformly across the district and surrounding areas by absorbing the workforce in large numbers, while patchouli oil industry with a distinctive aroma has penetrated the international market. Plants patchouli and patchouli oil industry (essential) to give high economic value added for those who manage it.
\end{abstract}

Keywords: core competence areas, One Village One Product, SAKA SAKTI, atsiri oil (essential).

\section{A. LATAR BELAKANG}

Kompetensi inti sebagaimana didefinisikan oleh Prahalad (1990) adalah sebagai kumpulan keterampilan dan teknologi yang memungkinkan suatu organisasi dapat menyediakan manfaat tersendiri bagi pelanggannya. Dengan demikian, kompetensi inti merupakan sekumpulan sumber daya dan kemampuan (aset-aset) organisasi yang memiliki keunikan tinggi yang diperlukan untuk mencapai tujuan-tujuan organisasi. Keunikan yang dimiliki organisasi dapat membuat kesulitan bagi pesaing untuk menirunya.

Dengan mengadopsi konsep one village and one product yang dikembangkan oleh Gubernur Hiramatsu di daerah Oita-Jepang dan konsep SAKA SAKTI (satu kabupaten/kota satu kompetensi inti) yang dipaparkan oleh Martani Huseini (2000) dalam pidato guru besarnya, maka untuk membangun daya saing daerah diperlukan penciptaan kompetensi inti bagi daerah tersebut. Hal ini diperlukan agar seluruh sumber daya dan kemampuan yang dimiliki oleh daerah tersebut terfokus pada upaya untuk menciptakan kompetensi inti. 
Dilihat dari dimensi mikro (perusahaan), Kotler (dalam Anonim: 2010) berpendapat bahwa organisasi dalam membangun kompetensi inti (produk/layanan/komoditi inti) setidaknya memperhatikan kriteria-kriteria seperti keunikan, sulit untuk ditiru, memberikan manfaat lebih bagi pelanggan serta memberikan keuntungan yang cukup besar. Sedangkan dilihat dari dimensi yang lebih luas, yaitu suatu daerah (Kabupaten/kota), pemilihan kompetensi intinya tidak boleh keluar dari kriteria-kriteria seperti memiliki nilai tambah yang tinggi, memiliki keunikan daerah, memiliki keterkaitan yang kuat serta memiliki peluang untuk menembus pasar internasional. Dengan kata lain, penentuan kompetensi inti suatu daerah haruslah memberikan dampak yang besar dalam menstimulus perekonomian daerah.

Permasalahan yang dihadapi oleh daerah saat ini antara lain karena konsep kompetensi inti (beserta manfaat-manfaatnya) belum diterapkan secara benar dalam perencanaan perekonomian daerah. Kalaupun sudah, konsep tersebut terkadang dipahami secara parsial atau tanpa mengindahkan kaidah-kaidah yang telah disebutkan di atas. Sehingga dalam kenyataannya, suatu kabupaten/kota seringkali hanya meniru apa yang terlihat berhasil dilaksanakan di daerah lain tanpa mempertimbangkan kemampuan internal dan peluang yang dihadapi oleh daerah tersebut.Akibatnya banyak proyek-proyek yang sifatnya replikasi yang gagal ketika diimplementasikan di lapangan. Permasalahan tersebut juga semakin diperparah oleh adanya pendekatan yang bersifat top-down dalam menentukan dan mengembangkan kompetensi inti sebab ide-ide yang muncul hanyalah ide pejabat daerah tertentu tanpa dikonfirmasikan ke masyarakat.

Berangkat dari hal-hal tersebut di atas, maka perlu dilakukan suatu penelitian untuk mengkaji lebih jauh tentang konsep kompetensi inti secara holistik, mulai dari penentuan kompetensi inti daerah hingga rencana mengimplementasikannya. Penelitian ini dilakukan di Kabupaten Belu Provinsi Nusa Tenggara Timur, untuk mengidentifikasi berbagai komoditi yang memenuhi kriteria kempetensi inti daerah. Dengan menemukan kompetensi inti daerah, selanjutnya dibuatkan rencana pengembangan dan implementasinya pada masa yang akan datang. Tujuan penulisan artikel ini adalah untuk mengkaji dan menyusun konsep kompetensi inti daerah yang menyeluruh mulai dari penentuan kompetensi inti hingga rencana implementasinya.

\section{B. KAJIAN TEORITIS}

Landasan teori yang digunakan untuk mengkaji penelitian ini adalah: dengan mengacu pada pemikiran C.K. Prahalad (1990). Pemikiran Prahalad yang paling populer bahkan hingga saat ini adalah mengenai core competence yang dituliskannya bersama Gary Hamel dalam Harvard Business Review. Menurut Rinella Putri dalam http://vibizmanagement.com/ journal.php? id $=199 \& s u b=$ journal\&page $=$ str mgt. dikatakan bahwa Prahalad dan Hamel berpendapat bahwa sebuah perusahaan harus menemukan kelebihan utamanya dan menjadi tidak terkalahkan dalam area tersebut. Produk-produk yang dihasilkan harus berdasarkan pada core competence tersebut.

Prahalad dan Hamel juga yang memperkenalkan konsep strategic intent, terutama setelah melihat serbuan perusahaan Jepang di industri otomotif dan elektronik. Keduanya melihat bahwa berbeda dengan perusahaan AS yang fokusnya jangka pendek, perusahaan Jepang punya strategi jangka panjang, dengan intention (tujuan) yang jelas. Keduanya juga menjelaskan 
mengenai perspektif resource-based, dimana perusahaan-perusahaan mencapai tujuan jangka panjangnya dengan mengembangkan kapabilitas mereka. Contohnya adalah Canon, yang punya core competence dalam Optik. Dengan mengejar tujuan jangka panjang dan mengembangkan kapabilitasnya, perusahaan-perusahaan Jepang dapat melangkahi pesaing-pesaingnya dari perusahaan AS, yang fokusnya cenderung jangka pendek.

Dalam "Competing for the Future" yang ditulis oleh Gary Hamel (1990), Prahalad memberikan saran bagi perusahaan supaya dapat merancang strategi yang jauh ke depan, dibandingkan dengan hanya mempertahankan status quo. Banyak perusahaan yang hanya fokus pada saat ini saja, dan tidak berusaha apapun untuk memperoleh keunggulan baru dan merancang masa depannya, sehingga kemudian kalah dengan pesaing mereka.

Selanjutnya, dalam buku "The Future of Competition: Co Creating Unique Value With Customers", Prahalad bersama Venkat Ramaswamy menghadirkan pendekatan baru dalam hal value-creation. Dalam framework yang diperkenalkannya, Prahalad dan Ramaswamy berpendapat bahwa perusahaan tidak seharusnya berusaha untuk menciptakan nilai sendirian, melainkan sebaiknya melakukan kolaborasi dengan pelanggan, sehingga dapat menciptakan suatu pengalaman pelanggan yang personalized sampai ke tingkat individual.

Namun, buku Prahalad yang paling idealis dan menjadi salah satu penggerak global movement adalah "The Fortune at the Bottom of The Pyramid". Buku ini mengemukakan mengenai business model dan peluang pasar yang ada pada masyarakat piramida paling bawah, yakni masyarakat miskin. Potensi pasar yang terbesar sesungguhnya ada di piramida bawah, sehingga meskipun perusahaan memproduksi barang-barang dengan harga murah yang memenuhi kebutuhan orang-orang berpendapatan rendah, namun tetap dapat menghasilkan keuntungan dengan business model tersebut. Business model seperti ini, menurutnya cocok digunakan di negara seperti India, yang masyarakat kelas bawahnya merupakan mayoritas.

Menurut Prahalad dan Hamel (1990), jika suatu organisasi/perusahaan ingin memenangi persaingan di masa depan maka organisasi/perusahaan tersebut harus lebih berorientasi pada upaya untuk merebut berbagai peluang (opportunity share) ketimbang pangsa pasar (market share) karena pangsa pasar yang diperoleh sesungguhnya bergantung pada kemampuan organisasi menciptakan peluang. Untuk merebut peluang masa depan, organisasi/perusahaan perlu memiliki kompetensi inti (core competence).

Kompetensi inti sebagaimana didefinisikan oleh Hamel dan Prahalad adalah kumpulan keterampilan dan teknologi yang memungkinkan suatu organisasi menyediakan manfaat tersendiri bagi pelanggannya. Dengan demikian, kompetensi inti merupakan sekumpulan sumberdaya dan kemampuan (aset-aset) organisasi yang memiliki keunikan tinggi yang diperlukan untuk mencapai tujuan-tujuan organisasi. Keunikan yang dimiliki organisasi dapat membuat kesulitan bagi pesaing untuk menirunya.

Bertolak pada kesadaran akan keunikan yang dimiliki oleh daerah, pendekatan yang digunakan dalam pembangunan daerah perlu dikembangkan dalam bentuk terpadu dengan perspektif jangka panjang dengan tidak hanya melulu mempertimbangkan kebutuhan sekarang berdasarkan konfigurasi yang ada (Pangestu dan Azis, 1994). Perspektif jangka panjang ini menegaskan bahwa pelaksanaan pembangunan itu harus dalam dirinya sendiri bersifat berkelanjutan (sustainable). Perspektif ini dapat berjalan seiring dengan gagasan peningkatan kemandirian daerah yang dirumuskan dalam UU No. 32 di atas. Kemandirian daerah secara 
implisit menunjuk pada kemampuan daerah untuk tumbuh, atau dengan kata lain pada suatu keadaan perkembangan aktivitas sosial-ekonomi yang terkelola dengan baik oleh Pemerintah Daerah. Kemandirian daerah secara berkelanjutan menjadi sebuah gagasan yang akan dapat memadukan berbagai konsepsi di atas secara menyeluruh.

Menurut Huseini (2000), dengan mengambil pemikiran mengenai konsep one village and one product (OVOP) yang dikembangkan oleh Gubernur Hiramatsu di daerah Oita-Jepang dan konsep SAKASAKTI (satu Kabupaten/Kota satu kompetensi inti) maka untuk membangun daya saing daerah diperlukan penciptaan kompetensi inti bagi daerah tersebut. Gagasan ini merupakan sebuah gerakan strategis yang dirancang khusus untuk pembangunan daerah. Konsep SAKASAKTI menyatakan bahwa masyarakat perlu menentukan satu produk atau industri yang sangat khas di daerahnya dan mengelolanya menjadi sebuah produk atau industri yang dapat diterima secara nasional, bahkan global. Produk atau industri tersebut haruslah dikembangkan berdasarkan kompetensi inti yang vital bagi pengembangan produk/industri yang bersangkutan.

Selanjutnya dikatakan bahwa dilihat dari dimensi mikro (perusahaan), bahwa organisasi dalam membangun kompetensi inti (produk/layanan/komoditi inti) setidaknya memperhatikan empat kriteria yaitu, memiliki keunikan, sulit untuk ditiru, memberikan manfaat lebih bagi pelanggan serta memberikan keuntungan yang besar. Jika dilihat dari dimensi yang lebih luas, yaitu suatu daerah (Kabupaten/Kota), kompetensi inti yang dipilih haruslah memenuhi kriteria sebagai berikut, yaitu, memiliki nilai tambah yang tinggi, memiliki keunikan daerah, memiliki keterkaitan yang kuat dengan sumberdaya yang dimiliki daerah, serta memiliki peluang untuk menembus pasar internasional. Dengan kata lain, penentuan kompetensi inti suatu daerah haruslah memberikan dampak yang besar dalam merangsang pertumbuhan ekonomi daerah.

Pada saat ini konsep SAKASAKTI dan kompetensi inti (beserta manfaat-manfaatnya) belum diterapkan secara terintegrasi dalam perencanaan perekonomian daerah. Beberapa daerah bahkan menyamakan pengertian kompetensi inti dengan pengertian produk unggulan. Akibatnya, konsep kompetensi inti dipahami secara parsial atau tanpa mengindahkan kriteria yang telah disebutkan di atas. Sehingga dalam kenyataannya, suatu Kabupaten/Kota seringkali hanya meniru apa yang terlihat berhasil dilaksanakan di daerah lain tanpa mempertimbangkan kemampuan internal dan peluang serta hambatan yang dihadapi oleh daerah tersebut. Akibatnya banyak proyek yang sifatnya replikasi yang gagal ketika diimplementasikan di lapangan. Permasalahan tersebut juga semakin diperparah oleh adanya pendekatan yang bersifat top down dalam menentukan dan mengembangkan kompetensi inti sebab ide-ide yang muncul hanyalah ide pejabat daerah tertentu tanpa dikonfirmasikan ke masyarakat. Dalam era globalisasi saat ini, konsep SAKASAKTI harus kembali diangkat sebagai upaya menyegarkan kembali pembangunan ekonomi daerah yang menekankan pada potensi daerah tersebut.

\section{METODE PENELITIAN DAN ANALISIS DATA}

Data dan informasi yang dibutuhkan diperoleh melalui focus group discussion (FGD) yang melibatkan pemerintah daerah, asosiasi bisnis, pelaku bisnis dan LSM serta perguruan tinggi di Kabupaten Belu. Data yang terkumpul selanjutnya diolah dengan metode Analitycal Hierarchy Process (AHP) yang dikemukakan oleh Saaty (1983). Adapun tahapan yang dilakukan adalah meminta peserta mengidentifikasi kompetensi inti daerah dan selanjutnya mengisi kuesioner yang berkaitan dengan Penetapan Bobot Kepentingan Indikator (Expert Judgement) dan kuesioner yang berkaitan dengan Persepsi Pelaku Usaha. 
Penetapan Bobot Kepentingan Indikator maupun persepsi pelaku usaha terdiri dari tujuh aspek utama yang meliputi Peringkat Indikator:

1. Bahan Baku

2. Sumber Daya Manusia

3. Daya Saing

4. Sarana dan Prasarana

5. Teknologi dan Informasi

6. Modal Sosial dan Kelembagaan

7. Kondisi Keamanan

Semua kompetensi inti daerah yang diinventarisir selanjutnya ditetapkan bobot kepentingan indikatornya dan persepsi pelaku usaha sesuai dengan tujuh aspek di atas. Selanjutnya komoditas dengan skor bobot tertinggi ditetapkan sebagai kompetensi inti daerah. Adapun kriteria pembobotan adalah:

Tabel 1. Kriteria Pembobotan Kompetensi Inti Daerah

\begin{tabular}{lll}
\hline NO & SKOR BOBOT & KATEGORI \\
\hline 1 & $>80-100$ & Tinggi \\
2 & $>60-80$ & Cukup \\
3 & $0-60$ & Rendah \\
\hline
\end{tabular}

Sumber: Anonim, 2010a

\section{HASIL DAN PEMBAHASAN}

\section{Proses Penetapan Kompetensi Inti Daerah di Kabupaten Belu}

\section{Stakeholders dan Penetapan Kompetensi Inti Daerah}

Adapun pihak-pihak yang terlibat dalam Focus Group Discussion (FGD) penentuan bobot kompetensi inti daerah di Kabupaten Belu adalah:

1) Dinas Perindustrian dan perdagangan Kabupaten Belu

2) Bagian Ekonomi Setda Kabupaten Belu.

3) Dinas Pertanian Kabupaten Belu.

4) Dinas Kehutanan dan Perkebunan Kabupaten Belu.

5) Unsur Kadin Kabupaten Belu.

6) Perwakilan Pengusaha Mebeler

7) Perwakilan Pengusaha Tenun Ikat

8) Perwakilan Pengusaha Gerabah

9) Perwakilan Pengusaha Petani Nilam

10) Perwakilan Pengusaha Minyak Nilam

11) Perwakilan LSM

12) Perwakilan Perguruan Tinggi.

Jumlah peserta yang hadir sebanyak 34 orang. Berdasarkan hasil olahan data primer (Expert Judgement dan Persepsi Pengusaha) dan didukung oleh data sekunder terkait, maka dengan menggunakan Analytical Hierarchy Process (AHP) diperoleh 4 komoditas/produk unggulan prioritas (hasil rangking AHP). Selanjutnya, dari keempat komoditas/produk unggulan 
prioritas tersebut, peserta FGD memberikan nilai 0-100 terhadap 7 aspek rantai nilai, dan hasilnya sebagai berikut:

Tabel 2. Pembobotan Komoditas Unggulan di Kabupaten Belu, 2010.

\begin{tabular}{llllll}
\hline NO & Aspek Rantai Nilai & \multicolumn{3}{c}{ Komoditas/Produk Unggulan Prioritas } \\
\cline { 3 - 6 } & & Nilam & Mebeler & Gerabah & Tenun Ikat \\
1 & Bahan Baku & 95 & 60 & 80 & 70 \\
2 & Sumber Daya Manusia & 90 & 80 & 65 & 80 \\
3 & Daya Saing & 85 & 40 & 60 & 60 \\
4 & Sarana dan Prasarana & 80 & 40 & 70 & 65 \\
5 & Teknologi dan Informasi & 65 & 40 & 40 & 75 \\
6 & Modal Sosial dan Kelembagaan & 90 & 70 & 75 & 90 \\
7 & Kondisi Keamanan & 70 & 65 & 65 & 70 \\
& JUMLAH BOBOT & 575 & 395 & 455 & 510 \\
& RATA-RATA BOBOT & 82,14 & 56,43 & 65,00 & 72,86 \\
\hline
\end{tabular}

Sumber: hasil olahan data lapangan berdasarkan FGD, 2010

Keterangan Skor Bobot : $>80-100=$ tinggi, $>60-80=$ Cukup, dan $0-60=$ Rendah

Dengan menggunakan kriteria yang ada maka dari keempat komoditi/produk unggulan prioritas yang memiliki nilai rata-rata tertinggi untuk ketujuh aspek yang dinilai berturut-turut:
1) Nilam
$: 82,14$
2) Mebeler
$: 56,43$
3) Gerabah
$: 65,00$
4) Tenun Ikat
$: 72,86$

Dengan demikian, disepakati oleh seluruh peserta FGD bahwa komoditi/produk unggulan prioritas yang menjadi kompetensi Inti Kabupaten Belu adalah Nilam (kesepakatan peserta diwujudkan dengan Berita Acara). Hasil penetapan tersebut ternyata sejalan dengan kebijakan Pemda Belu yang ingin menjadikan Nilam dan Minyak Nilam sebagai pengganti Cendana dan Minyak Cendana yang kini telah punah. Dengan penetapan kompetensi inti daerah tersebut maka selanjutnya dirumuskan arah pengembangan produk Tanaman Nilam dan Industri Minyak Nilam, Prospek Pasar, Teknologi, Kelayakan Ekonomi, Dampak Sosial dan Lingkungan, serta Penetapan Strategi Pengembangan.

\section{Arah Pengembangan Produk}

\section{Sasaran pengembangan produk}

1) Kabupaten Belu berbatasan langsung dengan Negara Timor Leste. Luas wilayah Kabupaten Belu adalah 2445,57 $\mathrm{KM}^{2}$. Ada dua kecamatan yang paling luas wilayahnya yaitu kecamatan Lamaknen dan Kecamatan Tasifeto Barat dengan luas masing-masing 214,31 $\mathrm{KM}^{2}$ dan 284,43 $\mathrm{KM}^{2}$. Pada kecamatan Lamaknen telah dikembangkan tanaman Nilam secara besar-besaran sejak tahun 2003; sementara pada kecamatan lainnya baru dikembangkan tanaman nilam dalam jumlah yang kecil. 
2) Dari tanaman Nilam inilah sekarang sedang dikembangkan Minyak Nilam yang merupakan salah satu komoditi unggulan prioritas di Kabupaten Belu. Saat ini telah ada beberapa pengusaha local yang sedang giat mengembangkan minyak nilam yang bahan bakunya berasal dari tanaman nilam.

3) Dari seorang pengusaha Minyak Nilam (IYOR AROMATIC) diperoleh keterangan bahwa sudah ada 20 Kelompok Usaha Bersama (KUB) yang tersebar pada empat Kabupaten di Daratan Timor yang telah menandatangani MOU dengan IYOR AROMATIC. KUB tersebut membeli bibit nilam dari IYOR AROMATIC dan hasilnya dijual kembali kepada IYOR AROMATIC sesuai dengan keadaan harga saat transaksi terjadi. Kontribusi terhadap perekonomian daerah dalam bentuk PAD belum nyata, tetapi kontribusi nyata saat ini adalah banyak tenaga kerja yang sebelumnya menganggur saat ini menggeluti usaha tanaman nilam. Kontribusi lainnya adalah peningkatan pendapatan di mana dalam satu hektar dalam tiga bulan terakhir dapat mendatangkan pendapatan sebesar Rp. 20.000.000,- (dua puluh juta rupiah). Dengan demikian, dalam sebulan setiap hektar lahan nilam dapat mendatangkan pendapatan rata-rata Rp. 6.666.000,- (enam juta enam ratus enam puluh enam ribu rupiah). Saat ini rata-rata dalam satu hektar terdapat tiga orang tenaga kerja sehingga dalam sebulan dapat mendatangkan pendapatan bagi setiap orang sebesar Rp. 2.222.000,- (dua juta dua ratus dua puluh ribu rupiah). Rata-rata pendapatan ini lebih besar dari gaji pokok seorang PNS golongan empat.

4) Satu tekad dari para pengusaha lokal dan Pemda Kabupaten Belu adalah menjadikan minyak nilam sebagai komoditi unggulan prioritas daerah NTT sebagai pengganti minyak cendana yang bahan bakunya sudah mulai punah. Hal ini beralasan karena minyak Nilam dari daratan Timor pada umumnya dan pada daerah tertentu khususnya di Kabupaten Belu mempunyai aroma yang khas dan tidak sama dengan aroma minyak nilam di daerah lain di Indonesia atau bahkan dunia. Oleh karenanya ke depan akan dikembangkan tanaman nilam secara besar-besar khusus di Kabupaten Belu dan umumnya pada tiga kabupaten lain di daratan Timor yaitu Kabupaten TTU, TTS dan kabupaten Kupang. Sejalan dengan itu para pengusaha akan menyiapkan mesin pengolahan yang lebih besar lagi.

5) Sasaran pelaku minyak nilam di Kabupaten Belu adalah semua stakeholders menikmati hasil dari nilam baik industri hulu, antara dan hilir dengan kemitraan yang saling menguntungkan. Pada suatu saat nanti minyak nilam Kabupaten Belu khususnya dan NTT umumnya menjadi komoditi primadona Indonesia di pasaran internasional.

\section{Lokasi pengembangan}

Mesin pengolahan minyak nilam saat ini berada di Kota Atambua, ibu kota Kabupaten Belu; ada juga mesin pengolahan milik pemerintah yang ditempatkan di Kecamatan Lamaknen tetapi jarang dioperasikan. Bahan baku minyak nilam tersebar pada beberapa kecamatan di Kabupaten Belu dan juga beberapa kecamatan di Kabupaten TTU, TTS dan Kupang. Dari 17 kecamatan di Kabupaten Belu sebanyak 11 kecamatan sudah mengembangkan tanaman nilam, lainnya tersebar di TTU, TTS dan Kabupaten Kupang. Dasar pertimbangan mesin pengolahan ditempatkan di Kota Atambua, Kabupaten Belu karena pertimbangan kedekatan dengan bahan baku. Dengan demikian dapat menghemat biaya transportasi. Sementara untuk pemasaran produk minyak nilam dapat ditempuh melalui transportasi darat, laut dan udara, mengingat kota atambua mempunyai akses transportasi ke berbagai jalur, baik darat, laut maupun udara. 


\section{Kebijakan pemerintah daerah (Pemda)}

Sampai sejauh ini dukungan pemerintah daerah terhadap pengembangan minyak nilam sebagai produk unggulan prioritas daerah belum dituangkan dalam bentuk peraturan daerah. Namun demikian dalam berbagai kesempatan pemerintah daerah senantiasasa menyerukan kepada pengusaha dan masyarakat petani untuk mengembangkan nilam secara besar-besaran. Sementara ini kebijakan pemda kab Belu baru dalam bentuk surat pernyataan dukungan menjadikan minyak nilam sebagai komoditi unggulan prioritas daerah. Ssampai sejauh ini belum ada kebijakan lain baik yang mendukung maupun menghambat pengembangan komoditi nilam di Kabupaten Belu atau NTT umumnya.

\section{Prospek Pasar}

\section{Permintaan dan Penawaran}

Permintaan pasar minyak nilam dating dari luar negeri. Selama ini permintaan terbesar datang dari Eropa dan Cina, sementara permintaan dalam negeri belum ada. Secara informal sudah banyak pengusaha Eropa yang berkunjung ke Kabupaten Belu dan menaruh minat pada permintaan minyak nilam. Terakhir permintaan minyak nilam secara kontinyu yaitu sebanyak 600 ton pertahun atau setiap bulan diminta 50 ton. Namun demikian kondosi pasokan minyak nilam belum mencukupi. Selain bahan baku yang masih terbatas, mesin pengolahan juga masih berada pada kapasitas yang rendah yaitu rata-rata 1 ton per hari.

Sementara ini permintaan pasar Eropa saja belum dapat dipenuhi, sementara pengusaha dari Cina juga sudah meminta dalam jumlah yang besar. Dengan demikian pasar minyak nilam masih terbuka lebar, baik pasar Eropa yang sudah dan sedang terealisisr, pasar Cina dan sebentar lagi pasar dari Negara lainnya seperti Jepang dan Taiwan.

\section{Tujuan Pemasaran}

Pasar yang sudah jelas adalah Eropa khususnya Jerman dan Cina. Pasar potensial dalam lingkup internasional adalah Jepang dan Taiwan serta Korea Selatan. Sementara pasar dalam negeri sampai sejauh ini belum ada permintaan, demikian juga pasar local NTT.

\section{Analisis Persaingan}

Persaingan dengan produk lainnya sampai sejauh ini belum berarti. Selama ini produk minyak nilam bersaing dengan minyak cendana tetapi produksi minyak cendana sudah jauh berkurang. Selain minyak cendana, minyak nilam juga bersaing dengan produk minyak wangi lainnya seperti berbagai jenis parfum. Persaingan ke depan adalah antar sesama pengusaha minyak nilam. Saat ini ada beberapa pengusaha minyak nilam di Kabupaten Belu, ada yang swasta murni dan ada pula yang bantuan pemerintah.

Persaingan ke depan adalah persaingan kualitas produk. Pengusaha yang dapat memproduksi minyak nilam dengan aroma yang khas akan mampu merebut pasar internasional; sementara pengusaha yang memproduksi minyak nilam dengan aroma yang tidak khas akan kalah bersaing. 


\section{Jalur Pemasaran}

Jalur pemasaran bahan baku nilam di Kabupaten Belu adalah jalur pemasaran langsung, yaitu dari para petani sebagai pemasok bahan baku dijual secara langsung kepada pengusaha yang memproduksi minyak nilam. Hal ini terjadi karena ada MOU antara pengusaha minyak nilam dengan para petani pemasok bahan baku minyak nilam. Sementara jalur pemasaran produk minyak nilam adalah jalur pemasaran langsung, yaitu dari para pengusaha minyak nilam di Atambua, Kabupaten Belu dijual secara langsung kepada para konsumen yang meminta secara langsung dari Eropa. Khusus daratan Eropa yang baru dilayani adalah pesanan dari Jerman, sementara dari Negara Eropa lainnya dan Cina belum dapat dipenuhi karena pasokan minyak Nilam yang masih terbatas. Mekanisme pemasaran seperti tersebut di atas akan tetap dipertahankan karena jika menempuh saluran distribusi yang panjang akan membawa konsekwensi terhadap ekonomi biaya tinggi karena tingginya margin pemasaran pada setiap jalur yang dilalui.

\section{Teknologi Produksi}

\section{Teknologi pengolahan}

Sampai sejauh ini budidaya nilam masih dilakukan secara tradisional, belum mengarah kepada manajemen usaha tani yang moderen dengan menggunakan berbagai teknologi yang ada. Ke depan, untuk menjamin mutu yang lebih baik dan juga produksi yang lebih optimal, akan diusahakan teknologi budidaya yang lebih moderen dengan menggunakan prinsip-prinsip manajemen agrobisnis dan agrioindustri yang tepat.

Sementara teknologi yang digunakan untuk pengolahan minyak nilam adalah dengan menggunakan mesih yang berkapasitas kecil dan sedang. Hasil produksi yang sudah ada menunjukkan bahwa pengolahan dengan mesin yang kecil menghasilkan minyak nilam dengan kualitas yang rendah; sementara pengolahan dengan mesin yang berkapasitas sedang menghasilkan minyak nilam dengan mutu yang lebih baik. Ada kemungkinan, pengolahan minyak nilam dengan menggunakan mesin yang lebih besar akan menghasilkan minyak nilam dengan mutu yang lebih baik.

Proses pengangkutan bahan baku dari pusat produksi nilam ke kawasan pengolahan dengan menggunakan mobil truk. Semua bahan baku nilam disimpan di gudang milik pengusaha dan sampai sejauh ini masih representative. Sedangkan teknologi pasca produksi adalah semua produk minyak nilam diisi dalam botol sesuai dengan ukuran tertentu, mulai dari ukuran kecil (10 CC sampai dengan ukuran besar (1 liter). Sampai sejauh ini belum ada teknologi untuk pelayanan purna jual.

\section{Standar mutu}

Hasil wawancara dengan direktur IYOR AROMATIC tanggal 24 Desember 2007 via telepon, bahwa produksi minyak nilam mengikuti standar mutu yang dipersyaratkan oleh departemen perindustrian dan perdagangan RI. Hasil uji laboratorium produk minyak nilam dari IYOR AROMATIC semuanya ada di Departemen Perindustrian dan Perdagangan RI di Jakarta. 


\section{Kelayakan ekonomi}

Tanaman Nilam dapat berumur sampai dengan empat tahun tetapi rata-rata umur produksi sampai dengan tiga tahun. Tanaman nilam dapat dipanen setiap tiga bulan, dengan demikian dalam setahun dapat dipanen sebanyak empat kali. Dalam setiap hektar lahan dapat ditanami 20.000 stek nilam. Dan sejak persiapan lahan sampai dengan panen perdana butuh waktu sekitar enam bulan. Selanjutnya butuh waktu tiga bulan untuk sekali panen. Setiap kali panen, satu pohon nilam dapat menghasilkan lebih kurang satu kg produksi nilam basah. Dengan demikian setiap hektar dapat menghasilkan 20 ton nilam sekali panen.

Dari produksi tersebut dapat menghasilkan 5 ton nilam kering. Dari produksi tersebut dapat menghasilkan 100 liter minyak nilam. Dengan harga yang berlaku di Kabupaten Belu saat ini sebesar Rp. 200.000,- per liter, maka dalam setiap kali panen pada setiap hektar dapat menghasilkan pendapatan sebesar Rp. 20.000.000,-. Dengan demikian setiap bulan dalam setiap hektar dapat mendatangkan pendapatan bagi pekerja/pemiliknya sebesar lebih kurang Rp. 6.666.000,. Oleh karena setiap hektar rata-rata terdapat tiga orang tenaga kerja maka setiap orang yang bekerja di kebun nilam mendapatkan pendapatan rata-rata sebesar Rp. 2.222.000,-.

\section{Dampak Sosial dan Lingkungan}

\section{Dampak Sosial}

Dampak positif: 1) Penyerapan tenaga kerja. Dampak positip pengembangan tanaman nilam dan produksi minyak nilam adalah tenaga kerja yang sebelumnya cenderung mencari kerja ke luar negeri seperti di Malaysia, Hongkong dan Singapura, sekarang menjadi tenaga kerja di Kampung sendiri. 2) Peningkatan pendapatan. Bekerja di kebun nilam mendatangkan pendapatan yang lebih tinggi yaitu rata-rata Rp. 2.222.000,- perorang per bulan dari pada bekerja sebagai buruh atau pembantu rumah tangga di luar negeri. Di luar negeri selain mendapatkan pendapatan yang lebih rendah yaitu rata-rata Rp.1.000.000,- per orang per bulan dan sering disertai pula dengan berbagai perlakuan yang kurang menyenangkan dari majikan.

Dampak negatif: sampai sejauh ini belum ada dampak negatip dari budidaya tanaman nilam di Kabupaten Belu dan sekitarnya.

\section{Dampak Lingkungan}

Dampak Positif: dengan adanya pengolahan minyak nilam, pamor pulau Timor pada umumnya dan Kabupaten Belu khususnya akan menjadi terkenal di seluruh dunia. Jika sebelum ini Pulau Timor terkenal sebagai gudang cendana, maka ke depan, dengan pengolahan minyak nilam secara besar-besaran diharapkan dapat mengharumkan nama pulau Timor sebagai penghasil minyak nilam dengan aroma yang khas dan nomor satu di dunia.

Dampak negatif: saat ini mesin pengolahan minyak nilam berada di tengah kota Atambua. Oleh karena itu, limbah minyak nilam baik limbah bahan baku maupun limbah proses pengolahan akan mengganggu lingkungan sekitarnya. Oleh karena itu perlu dilakukan pengamanan sejak dini termasuk studi mengenai dampak lingkungan sehingga tidak menimbulkan klaim baik dalam jangka pendek, menengah maupun panjang. 


\section{Analisis Rantai Nilai}

\section{Sistem nilai generik}

Sumber bahan baku utama minyak nilam adalah para petani di perdesaan daratan Timor; sementara mesin pengolahan minyak nilam berada di Kota Atambua Kabupaten Belu. Produk nilam yang dihasilkan petani dibeli dan diangkut oleh pengusaha (pengelola minyak nilam) ke pusat pengelolaan di Kota Atambua. Alat angkut yang digunakan adalah mobil truk. Dengan demikian distribusi bahan bakunya dilakukan secara langsung yaitu dari petani penghasil langsung ke pengusaha pengelola. Produk akhir berupa minyak nilam dijual secara langsung oleh pengusaha ke konsumen akhir berdasarkan kesepakatan awal. Konsumen akhir saat ini berada di Benua Eropa dan yang baru dilayani adalah dari Negara Jerman. Dengan demikian antara pengusaha pengelola minyak nilam memainkan dua peran sebagai perantara, yaitu melalkukan MOU dengan petani penghasil untuk kebutuhan bahan baku dan MOU dengan konsumen akhir untuk penjualan produk akhir berupa minyak nilam. Dengan demikian ada dua mata rantai distribusi, yaitu petani penghasil - pengusaha pengelola - konsumen akhir.

Pada tingkat petani nilai pembelian adalah Rp.1.000,- per kg produk nilam basah. Dalam setiap hektar ditanami 20.000 stek nilam dan setiap pohon nilam dalam sekali panen dapat menghasilkan $1 \mathrm{~kg}$. Dengan demikian dalam setiap hektar dapat menghasilkan $20.000 \mathrm{~kg}$ nilam basah. Dengan harga setiap kg adalah Rp. 1000,- maka dalam setiap hektar dapat menghasilkan Rp. 20.000.000,- bagi pemiliknya. Setiap 20 ton nilam basah dapat menghasilkan 5 ton nilam kering, dan dari padanya dapat menghasilkan 100 liter minyak nilam. Dengan demikian pada tingkat petani setiap liter minyak nilam seharga Rp. 200.000,- Pada tingkat konsumen akhir setiap produk minyak nilam dijual dengan harga rata-rata Rp.400.000,- per liter. Setelah dikurangi berbagai komponen biaya pada setiap saluran distribusi dengan mempertimbangkan jarak tempuh antara kedua saluran yang ada di mana saluran produsen - pengusaha dengan jarak dalam satu daratan/pulau sementara saluran pengusaha - konsumen akhir dengan jangkauan jarak antar benua, maka saluran yang paling efisien saat ini adalah saluran dari produsen penghasil ke pengusaha pengelola minyak nilam.

\section{Rantai nilai lintas batas}

Pengembangan berbagai produk saat berfondasi pada ekonomi sisi permintaan. Artinya pengusaha berani menghasilkan produk jika telah ada permintaan atau pasar yang jelas. Pasar untuk produk minyak nilam dari Belu saat ini adalah Eropa dan Cina tetapi belum dipenuhi secara optimal. Hal demikian terkait dengan penyediaan bahan bakhu dan juga kapasitas mesin pengolah. Saat ini sumber bahan baku tersebar hampir merata di seluruh kecamatan di Kabupaten Belu. Tetapi permintaan pasar produk minyak nilam yang tinggi sementara persediaan bahan baku yang belum mencukupi maka sekarang ini telah dikembangkan tanaman nilam di kebupaten lain di daratan Timor seperti di Kabupaten TTU, TTS dan kabupaten Kupang. Dengan demikian kabupaten lain di luar Belu merupakan daerah belakang/hinterland sebagai pemasok tambahan bahan baku minyak nilam. Para petani produsen nilam tergabung dalam KUB yang menandatangani MOU dengan IYOR AROMATIC sehingga tidak ada kendala pemasaran bagi para produsen. Adapun alat transportasi yang digunakan untuk mengangkut bahan baku nilam dari petani produsen ke pengusaha pengelola adalah dengan menggunakan mobil truk. 
Sementara pemasaran produk akhir minyak nilam ke benua Eropa dengan menggunakan jalur transportasi udara.

Dengan adanya daerah belakang sebagai pemasok bahan baku tambahan maka pada saatnya berapapun permintaan produk minyak nilam dapat terpenuhi. Persoalan lanjutan terletak pada kapasitas mesin pengelola. Jika ada keseimbangan antara pasokan bahan baku dengan kapasitas mesin pengelola dan rencana operasi diprogramkan secara teratur maka berbagai kendala yang ada terkait kelebihan permintaan dapat diatasi atau diminimalisir.

Kendala utama dalam keterkaitan lintas batas adalah adanya berbagai retribusi baik resmi maupun tidak resmi pada berbagai pos perbatasan antar kabupaten. Kendala lainnya adalah kekawatiran akan keberlanjutan permintaan minyak nilam karena para petani produsen tidak mengetahui pasar atau potensi permintaan secara jelas. Untuk mengatasi hal yang demikian perlu adanya semacam aturan dari pemda yang mengakomodir bahwa minyak nilam akan dikembangkan sebagai komoditas unggulan prioritas sehingga ketika para pengusaha tidak dapat menampung hsil produksi petani dengan harga yang wajar maka pemerintah dapat bertindak sebagai pengaman dengan membeli produk petani tersebut.

\section{Rantai nilai industri}

Perusahaan IYOR AROMATIC yang dijadikan unit analisis, saat ini mempekerjakan tiga orang tenaga kerja. Berkat kerjasama dengan petani produsen melalui MOU, perusahaan ini tidak mengalami kendala dalam penyediaan bahan baku. Kendala utama aadalah kapasitas mesin pengelola yang masih terbatas sehingga belum mampu memenuhi kebutuhan permintaan pasar Eropa dalam jumlah besar. Perusahaan ini telah menyiapkan pergudangan sesuai kapasitas mesin. Saat ini perusahaan telah melaksanakan pendidikan alam terbuka bagi para petani produsen juga bagi karyawan yang bekerja pada perusahaan tersebut. Berkat pendidikan dan pelatihan teknis yang terkait dengan pengelolaan minyak nilam, para karyawan mempunyai kemahiran yang cukup membanggakan mulai dari proses operasi sampai dengan pengepakan dan dikirim ke luar negeri.

Menurut pengakuan pengelola, saat ini bahan baku pada tingkat petani produsen mempunyai kualitas yang tidak jauh berbeda antara satu dengan lainnya. Hal yang membedakan kualitas produk minyak nilam terletak pada mesin pengelola. Menurut pengelola IYOR AROMATIC, semakin besar mesin pengelola akan menghasilkan produk minyak nilam dengan kualitas yang semakin baik. Hal demikian sudah terbukti di mana ketika pengelolaan pada tingkat petani produsen dengan mesin bantuan pemerintah yang tergolong kecil, standar kualitas minyak nilam tidak memenuhi standar seperti ditetapkan departemen perindustrian dan perdagangan RI. Ketika bahan baku yang sama dikelola dengan mesin IYOR AROMATIC, ternyata dapat menghasilkan minyak nilam sesuai stantar departemen perindustrian dan perdagangan dan dengan aroma yang khas, yang tidak terdapat di daerah atau negara manapun. Diperkirakan nilam Timor akan menghasilkan minyak nilam dengan aroma yang khas, yang tiada duanya di dunia ini. Dan inilah yang akan menjadi keunggulan minyak nilam Timor di Kabupaten Belu.

Dengan demikian, keunggulan pertama minyak nilam Timor terletak pada bahan bakunya, yaitu tumbuh dari tanah Timor dengan aroma yang khas seperti cendana pada jamannya, dan keunggulan kedua terletak pada proses operasi dengan menggunakan mesin pengelola yang lebih besar dan baik yang memungkinkan proses produksi berjalan dengan lancar. 


\section{Penyusunan Strategi Pengembangan dan Rencana Aksi}

Dari analisis deskriptif terdahulu, maka produk unggulan prioritas saat ini adalah pertama bahan baku berupa tanaman nilam yang tumbuh di tanah Timor dengan aroma yang khas. Keunggulan kedua terletak pada produk akhir berupa minyak nilam, yaitu melalui proses produksi yang baik maka akan menghasilkan minyak nilam yang beraroma khas Timor dengan memenuhi ketentuan perindustrian dan perdagangan RI.

\section{Analisis SWOT (dilakukan pada tingkat industri)}

Analisis SWOT dilakukan deengan mengidentifikasi Kekuatan dan Kelemahan (faktor internal) dan peluang dan ancaman (faktor eksternal) pada industri yang dikembangkan. Selanjutnya dibuat matriks strategi yang merupakan hasil identifikasi tersebut.

Tabel 3. Matrix SWOT Industri Nilam dan Minyak Nilam di Kabupaten Belu, 2010.

\begin{tabular}{|c|c|c|}
\hline Faktor Eksternal & $\begin{array}{l}\text { Kekuatan (S) } \\
\text { SDM pengelola memadai } \\
\text { Peralatan mesin ada. } \\
\text { Bahan baku tersedia sesuai } \\
\text { kebutuhan saat ini. } \\
\text { Aroma minyak nilam Belu sangat } \\
\text { khas dan beda dengan minyak } \\
\text { nilam dari daerah atau negara lain. }\end{array}$ & $\begin{array}{l}\text { Kelemahan (W) } \\
\text { Peralatan mesin berkapasitas } \\
\text { sedang; } \\
\text { Bahan baku tersebar pada } \\
\text { beberapa wilayah kecamatan } \\
\text { dan kabupaten, tidak terpusat. } \\
\text { Harga sering berubah-ubah. }\end{array}$ \\
\hline $\begin{array}{l}\text { Peluang (0) } \\
\text { Permintaan pasar } \\
\text { besar } \\
\text { Jumlah pesaing } \\
\text { terbatas. }\end{array}$ & $\begin{array}{l}\text { Strategi SO } \\
\text { Menciptakan kemitraan yang saling } \\
\text { menguntungkan antara pengusaha } \\
\text { pengelola dengan petani produsen } \\
\text { untuk menjaga kesinambungan } \\
\text { persediaan bahan baku sehingga } \\
\text { proses operasi terus berlangsung } \\
\text { untuk menjawab permintaan pasar } \\
\text { yang terus meningkat. }\end{array}$ & $\begin{array}{l}\text { Strategi WO } \\
\text { Menambah kapasitas mesin } \\
\text { pengelolaan untuk tetap } \\
\text { menjaga mutu produk disertai } \\
\text { dengan membentuk pusat } \\
\text { jaringan distribusi bahan baku } \\
\text { serta jaminan harga yang stabil } \\
\text { dan transparan. }\end{array}$ \\
\hline $\begin{array}{l}\text { Ancaman }(\mathrm{T}) \\
\text { Peraturan } \\
\text { pemerintah berubah- } \\
\text { ubah. } \\
\text { Pengusaha baru } \\
\text { dengan mesin } \\
\text { produksi yang lebih } \\
\text { besar dan harga } \\
\text { yang lebih murah. }\end{array}$ & $\begin{array}{l}\text { Strategi ST } \\
\text { Aroma minyak nilam Timor yang } \\
\text { khas, dapat mengharumkan } \\
\text { kembali nama Timor di seantero } \\
\text { nusantara dan Dunia setelah } \\
\text { cendana punah. Untuk itu perlu } \\
\text { dibuat peraturan pemerintah seperti } \\
\text { perda untuk melindungi petani } \\
\text { produsen dan pengusaha lokal } \\
\text { sehingga ada kepastian usaha di } \\
\text { bumi Timor. }\end{array}$ & $\begin{array}{l}\text { Strategi WT } \\
\text { Memanfaatkan mesin produksi } \\
\text { yang lebih besar serta adanya } \\
\text { jaminan peraturan pemerintah } \\
\text { sehingga proses produksi mulai } \\
\text { dari tingkat petani produsen } \\
\text { sampai dengan pengusaha } \\
\text { pengelola dapat berlangsung } \\
\text { dalam persaingan yang sehat. }\end{array}$ \\
\hline
\end{tabular}

\section{Penetapan Sasaran}

\section{Sasaran jangka pendek:}

Untuk pasokan bahan baku/Industri Terkait:

1) Sosialisasi kepada petani produsen tentang pentingnya tanaman nilam sebagai bahan baku minyak nilam dengan berbagai keuntungan berupa perluasan kesempatan kerja maupun pendapatan bagi petani produsen. 
2) Perluasan areal tanaman nilam baik dalam wilayah desa yang telah melakukan budidaya, maupun ekspasnsi ke wilayah lain yang belum dikembangkan.

3) Membentuk kemitraan dengan semua pihak.

Untuk industri Penunjang, sasarannya adalah: penyediaan alat transportasi secara memadai guna mengangkut sarana produksi ke petani produsen, maupun pengangkutan bahan baku dari petani produsen ke lokasi pengolahan minyak nilam.

Untuk industri inti, sasarannya adalah melakukan produksi sesuai dengan pasokan bahan baku dan kapasitas mesin yang ada.

\section{Sasaran jangka menengah:}

Untuk pasokan bahan baku sebagai industri Terkait: sasarannya adalah Peningkatan produksi bahan baku nilam pada semua wilayah budidaya. Peningkatan produksi diharapkan disertai pula dengan peningkatan pendapatan petani produsen.

Untuk industri Penunjang, sasarannya adalah kelancaran pengangkutan sarana produksi dari pengusaha pengelola minyak nilam ke sentra produksi nilam; sebaliknya terjadi kelancaran pengangkutan bahan baku dari sentra produksi bahan baku nilam ke sentra pengolahan minyak nilam. Hal demikian selanjutnya akan mendukung kelancaran produksi, baik produksi bahan baku maupun produksi minyak nilam.

Untuk industri inti, sasarannya adalah peningkatan produksi minyak nilam dan dengan demikian peningkatan pendapatan bagi pengusaha pengelola minyak nilam dan tenaga kerja yang terkait.

\section{Sasaran jangka panjang:}

Untuk pasokan bahan baku/industri Terkait: sasarannya adalah peningkatan produksi dan ketesediaan produksi sebagai bahan baku secara memadai dengan kualitas yang semakin baik dan kesinambungan produksi secara teratur sesuai dengan rencana operasi pihak pengelola minyak nilam. Pada tahapan jangka panjang ini diharapkan adanya peningkatan produksi menjadi lebih dari $1 \mathrm{~kg}$ per pohon; tenaga kerja juga diharapkan meningkat dan dapat lebih dari 3 orang tenaga kerja setiap hektar; serta pendapatan per orang juga lebih besar dari Rp. 2.222.000,- per orang per bulan.

Untuk industri Penunjang: sasarannya adalah: semakin lancarnya pengangkutan sarana produksi dan bahan baku baik dari pengusaha pengelola ke petani produsen maupun sebaliknya dengan waktu yang terstandardisasi sehingga antara sentra produksi bahan baku dengan sentra produksi minyak nilam tidak terdapat kesenjangan yang berarti. Kesenjangan tersebut dapat berupa lambatnya pasokan sara produksi seperti bibit, pupuk, obat-obatan, pacul, skop, dan sebagainya. Sebaliknya kesenjangan pengangkutan bahan baku dapat berupa keterlambatan pengangkutan bahan baku, kemacetan di jalan atau pos perbatasan antar kabupaten dan sebagainya.

Untuk industri inti, sasarannya adalah peningkatan produksi minyak nilam secara berkesinambungan dengan kualitas yang semakin baik, aroma yang semakin khas, pengepakan yang semakin menarik, dan juga diversifikasi produk dari minyak nilam seperti minyak obat, minyak pijat, wewangian lain dan sebagainya. Pada tahapan sasaran yang jelas adalah kapasitas mesin pabrik sudah lebih besar dari yang sekarang, tenaga kerja sudah lebih dari tiga orang dan pendapatan pengusaha sudah lebih dari Rp. 400.000,- per liter. 


\section{Penetapan Strategi}

Strategi jangka pendek adalah: Menciptakan kemitraan yang saling menguntungkan antara pengusaha pengelola dengan petani produsen untuk menjaga kesinambungan persediaan bahan baku sehingga proses operasi terus berlangsung untuk menjawab permintaan pasar yang terus meningkat.

Strategi jangka menengah adalah: Menambah kapasitas mesin pengelolaan untuk tetap menjaga mutu produk disertai dengan membentuk pusat jaringan distribusi bahan baku serta jaminan harga yang stabil dan transparan. Aroma minyak nilam Timor yang khas, dapat mengharumkan kembali nama Timor di seantero nusantara dan Dunia setelah cendana punah. Untuk itu perlu dibuat peraturan pemerintah seperti perda untuk melindungi petani produsen dan pengusaha lokal sehingga ada kepastian usaha di bumi Timor.

Strategi jangka panjang adalah: Memanfaatkan mesin produksi yang lebih besar serta adanya jaminan peraturan pemerintah sehingga proses produksi mulai dari tingkat petani produsen sampai dengan pengusaha pengelola dapat berlangsung dalam persaingan yang sehat.

\section{E. KESIMPULAN DAN REKOMENDASI}

\section{Kesimpulan}

Minyak nilam layak menjadi komoditi unggulan prioritas Kabupaten Belu. Beberapa aspek yang mendukung pengembangan minyak nilam sebagai komoditi unggulan prioritas adalah:

1. Aroma minyak nilam Kabupaten Belu sangat khas dengan kualitas nomor satu di dunia. Aroma yang khas tersebut sangat tergantung pada jenis tanah di daratan Timor umummnya dan Kebupaten Belu khususnya. Hampir setiap wilayah mempunyai aroma nilam yang khas dan spesifik.

2. Hamparan pertanian di Kabupaten Belu khususnya dan daratan Timor umumnya masih luas dan potensial untuk pengembangan tanaman nilam sebagai bahan baku minyak nilam.

3. Penggunaan mesin pengelola minyak nilam sangat mempengaruhi kualitas dan aroma minyak nilam. Penggunaan mesin pengelola yang semakin besar diperkirakan lebih menjamin mutu dan menjamin aroma yang tetap khas.

4. Pengembangan minyak nilam sebagai komoditi unggulan prioritas tidak dapat berdiri sendiri. Pengembangan tersebut terkait dengan bahan baku pada salah satu sisi dan juga penyediaan bibit dan sarana produksi lainnya pada sisi yang lain serta tersedianya prasarana dan sarana transportasi yang memadai.

\section{Rekomendasi}

1. Segera dilakukan sosialisasi kepada petani produsen tentang pentingnya minyak nilam dan industri terkait dan pendukungnya sebagai upaya peningkatan kesempatan kerja dan pendapatan bagi masyarakat yang selama ini berada pada tingkat hidup yang miskin.

2. Perlu dibuatkan perda tentang pengembangan komoditas nilam sebagai komoditas unggulan prioritas disertai dengan aturan teeknis lainnya sehingga tidak terjadi hambatan pasokan bahan baku pada berbagai wilayah perbatasan termasuk pungutan liar yang sangat merugikan pengusaha setempat. 
3. Bantuan pengadaan mesin pengelola bagi pengusaha setempat guna mendapatkan kualitas minyak nilam yang baik dengan tetap menjadi aroma khas minyak nilam Timor sebagai salah satu alternatif pengganti minyak cendana pada masa yang akan datang.

\section{DAFTAR PUSTAKA}

Anonim, 2010a. Laporan Hasil Penelitian Kompetensi Inti Daerah Kabupaten Mamuju, Sulawesi Selatan. Saketi, 2010.

Anonim, 2010b. Menyegarkan kembali Konsep SAKASAKTI. http://market-insight.blogspot.com/ 2008/06/menyegarkan-kembali-konsep-sakasakti.html

Anonim, 2009. Kabupaten Belu Dalam Angka Tahun 2008. BPS Kabupaten Belu. 2009.

Mari Pangestu \& Iwan Azis, 1994. " Survei Perkembangan terbaru, " Buletin Studi Ekonomi Indonesia , Taylor dan Jurnal Francis, vol. 30 (2), halaman 3-47.

Martani Huseini. 2000. Otonomi Daerah, Integrasi Bangsa, dan Daya Saing Nasional: Saka-Sakti, Suatu Model Alternatif pemberdayaan Ekonomi Daerah (orasi Ilmiah Wisuda XIX STIA LAN Bandung, tanggal 29 April 2000)

Prahalad, C.K. and Hamel, G (1990). The Core Competence of the Corporation, Harvard Business Review (v. 68, no. 3) pp. 79-91.

Rinella Putri. http://vibizmanagement.com/journal.php? id=199\&sub=journal\&page $=$ str mgt. Rabu, 28 April 2010 06:30 WIB;

Saaty, Thomas.L., The Analytic Hierarchy Process, McGraw-Hill, New York. 1980. 